\title{
The European Network of Biogenetic Reserves*
}

$\mathrm{I}_{\mathrm{h}}$ Europe at present it is estimated that $22 \%$ of the higher-order plants, $52 \%$ of fish species, and $42 \%$ of the species of mammals, are on the way to becoming extinct. This alarming situation is due to the erosion and deterioration of natural habitats - wetlands most especially - and the worsening monotony of Europe's landscapes, with their expanding human settlements and vast areas under over-intensive cultivation. As a result, not only are the natural balances of the planet Earth at risk: we are also losing valuable cultural and aesthetic assets and impoverishing our heritage.

One means of stemming this dangerous trend is to create and maintain truly protected areas. Two networks of protected areas have been created by the Council of Europe: the European Diploma network, and the European Network of Biogenetic Reserves - founded in 1965 and 1976 , respectively.

\section{Foundation of European Biogenetic Reserves Network}

It was in Vienna in 1973, at the first European Ministerial Conference on the Environment organized by the Council of Europe, that the idea was launched of inaugurating a programme for the conservation of representative samples of natural habitats of various types as a means of protecting the flora and fauna of Europe. This programme entered a new phase in 1976 with the creation of the European Network of Biogenetic Reserves.

The Member States that are engaged in this action undertake to cooperate in order to identify and protect natural habitats which are of particular value for Nature conservation in Europe. The Network offers Member States an international framework in which to cooperate and coordinate their policies regarding the creation of protected areas, so that these latter may assume a complementary and mutually reinforcing role in the survival of all that can be saved of Europe's biological diversity.

Since 1976, this will to cooperate has continued undiminished. The Network is one of the key aids to the direct implementation of Article 4 of the Council of Europe Convention on the Conservation of European Wildlife and Natural Habitats, or Bern Convention ${ }^{\dagger}$, which is one of the principal Nature conservation conventions applicable to Europe. Article 4 enshrines the obligations of governments to conserve the habitats of wild flora and fauna, in particular of those species which are listed in Appendices I and II as being strictly protected.

\section{Objectives of the Network}

The objectives of the Network are set out, in Resolution (76) 17, among the requirements decided on by the Committee of Ministers of the Council of Europe. Every biogenetic reserve must:

- contribute to the maintenance of the biological balance and the conservation of representative samples of Europe's natural heritage; and

- act as a 'living laboratory' for research into the operation and evolution of natural ecosystems. The

* Adapted from Naturopa Environment Features Nr 92-1, 1992. - Ed.

${ }^{\dagger}$ See pages $272-4$ of this issue. - Ed. scientific knowledge thus acquired can then be put to use in campaigns to generate public interest in environmental issues and duly provide information and instruction.

\section{Criteria for Choice of Biogenetic Reserves}

The purpose of a biogenetic reserve is to preserve habitats or ecosystems, whether terrestrial, aquatic, or otherwise. As a rule, the areas concerned must be natural, but they may also be semi-natural; a semi-natural area is one which has long since gone out of cultivation or one which is biologically rich despite being Man-made and still in use. Examples of semi-natural habitats include extensive grasslands, polders, and artificially-created wetlands. In some cases, environmentally benign human intervention may be necessary to maintain the area in its desired state. It is often the case with freshwater or brackish wetlands that the reeds (Phragmites spp.) or other coarse Gramineae or sedges have to be cut down at regular intervals in order to prevent water-levels from sinking over a period of time.

There is no limit to the size of a biogenetic reserve. A small patch of dry grass on which a rare plant subsists would qualify: so would a vast area of maquis, peatland, or tundra. The size of a reserve must simply be appropriate to the objectives that have been set for the conservation of one or more ecosystems and/or particular species. In the case of a very small reserve, a surrounding protective 'buffer zone' may sometimes prove necessary.

The selection of biogenetic reserves is generally made on the basis of two criteria:

- their value for Nature conservation; and

- the status of their protection.

The value of a biogenetic reserve for Nature conservation is judged by the degree to which the habitats which it encompasses, or the species that take refuge there, are typical, unique, rare, or endangered. Biogenetic reserves are commonly ecocomplexes involving a plurality of different ecosystems. Thus each biogenetic reserve is of value for the conservation of Europe's natural heritage because it harbours ecosystems or species that are typical, unique, rare, and/or endangered. In fact it is usual for a reserve to comprise several ecosystems and harbour not just one but many interesting species.

The protection status of a biogenetic reserve must be sufficient for its long-term conservation or its management in accordance with the proposed objectives. Every country has its own terminology of protected areas, but Resolution (73) 30 of the Committee of Ministers of the Council of Europe shows how to establish correlations and gauge the degree of protection afforded to each type of area. For instance, a biogenetic reserve may have the status of a Forest Reserve, a Partial Nature Reserve, a Strict Nature Reserve, or even a National Park. But in every case the protection status of a reserve must be compatible with the conservation objectives assigned to the area.

\section{Selecting Biogenetic Reserves}

In selecting biogenetic reserves, there are two complementary approaches, as follows: 
The Directed Approach:- This is an endeavour to establish a common European policy in the light of the priorities that have been laid down by the competent intergovernmental committee. Priority may, for example, be given to the conservation of heathlands, dry grasslands, flood-plains, peat-bogs, sand-dunes, etc. This approach is revised periodically.

Under the directed approach, the Council of Europe commissions experts to compile European inventories of existing sites in the Member Countries which match the agreed conservation priorities. Existing national and international inventories provide the basic 'raw material' from which selections are made according to the Network's rigorous criteria. The site-lists thus obtained enable proposals to be made to the member States. Sites of which the protection status is already sufficient, may be directly integrated with the Network upon application being made by the country concerned. Sites which are of European importance but do not yet benefit from any protection, are drawn to the attention of governments via the inventories, and may be included in the Network after their protection status has been improved.

The directed approach has the advantage of being methodical and meticulous: all the priority habitats and species are studied in succession on a Europe-wide basis. On the other hand, this is a time-consuming process, and so it may be useful from time to time to combine it with the non-directed approach.

The Non-directed Approach:- For inclusion in the Network, governments may offer any adequately protected site of European importance for Nature conservation which matches the criteria of biogenetic reserves without its necessarily being the biotope or wider habitat of what, under the directed approach, would be recognized as a priority species.

The non-directed approach is much more flexible than the directed: new additions to the Network can be made quickly, whenever suitable reserves come to light in one country or another.

\section{Keeping the Network Under Review}

Member governments notify the Council of Europe of the parts of their territory which they wish to have included in the Network. They do this by supplying the Council of Europe with a detailed descriptive card [a model is appended to Resolution (79) 9 of the Committee of Ministers], together with a map showing how the reserve fits into the landscape.

At its annual meeting, the competent intergovernmental committee examines each candidature carefully and decides which to accept for inclusion, which to defer for further study, and which to reject outright. Its decisions are notified to the governments, which then arrange for the symbol of the network to be displayed at each newly-designated reserve.

Reserves may normally be included in the Network for an unlimited period of time. However, the governments undertake to notify the committee of any alteration to the site which might undermine its biological value, and to provide updated information at five-yearly intervals.

In the event of a site coming under threat, the intergovernmental committee sends the government concerned a reminder to take the necessary remedial measures. If the threat is not removed and damage is caused, the Committee of Ministers of the Council of Europe advises the government to withdraw the reserve from the Network. Alternatively, any state may withdraw a reserve from the Network at any time. Situations such as these have, fortunately, never arisen so far.*

\section{The Network at Present}

At the present time, the Network comprises 287 reserves (involving a total area of 3,100,000 hectares) in 17 member countries of the Council of Europe. With new proposals coming in from European governments year by year, the Network continues the work of protecting Europe's natural heritage, by acting as both a stimulus and a reward.

\section{MARIE-AUdE L'HYVER, Administrator Environment Conservation and Management Division Council of Europe PB 431 R6 F-67006 Strasbourg Cedex France.}

*We welcome and applaud this practical indication of success provided it is rigidly applied. - Ed.

\section{[Continued from page 267]}

We feel it is important as well as urgent to conserve Lac des Oiseaux, and we hope quite ardently that the lake will be given full protection by declaring it a sanctuary for wildlife or by integrating it to El Kala National Park. In either case, we hope that action is also taken to ensure effective protection by means of recruiting workers and management, and by always enforcing the law.

\section{REFERENCES}

ANSTEY, S. (1989). The status and conservation of the White-head Duck, Oxyura leucocephala. IWRB Spec. Publ. 10, 125 pp.

Cote, M. (1974). Carte Bioclimatique de l'Est algérien. I.S.T. University, Constantine, Curer, carte au $1 / 1,000,000^{\circ}+$ notice.

Dumont, H.J. (1977). An analysis of the Odonata of Tunisia. Bull. Ann. Soc. Roy. Belge Ent., 113, pp. 63-94.

JolEAUd, L. (1936). Etude Géologique de la Région de Bône et La Calle, Bull. Serv. Carte Géol. Algérie, Typo-Litho et Cie, Alger, $2^{\circ}$ série, $n^{\circ} 12,185$ pp., 4 pl., 25 figs \& tab.

Lohmann, H. (1990). Enallagma cyathigerum (Charp.) in Marokko: Erstnachweis für Nordafrika (Zygoptera: Coenagrionidae). Notulae Odonatologicae, 3(5), pp. 65-80.

MCLachlan, R. (1897). Odonata collected by the Rev. E.A. Eaton in Algeria, with annotations. Ent. Mon. Mag., 8(2), pp. 152-7.

Quezel, P. \& Santa, S. (1962). Nouvelle Flore de l'Algérie. CNRS, Paris, France: pp. $1,170 \mathrm{pp}$.

RoI, O. LE (1915), Odonaten aus der Algerischen Sahara von der Reise von Freihern H. Geyr von Schweppenburg: Mit einer Übersicht der Nordafrikanischen Odonaten-fauna. Deutsch Etn. Z., pp. 609-34.

Samraoui, B., Benyacoub, S. \& Mecibah, S. (in press). Rediscovery of two relict dragonflies in Algeria, Notu. Odonatol.

Stevenson, A.C., SKInNer, J., Hollis, G.E. \& SMART, M. (1988). The El Kala National Park and environs, Algeria: An ecological evaluation. Environmental Conservation, 15(4), pp. 335-48, 2 maps and 3 tables.
B. SAMraOUI,
G. DE BELAIR, \&
S. BENYACOUB
Institute of Natural Sciences
University of Annaba
BP 12 El Hadjar
Annaba, Algeria. 